\title{
Study on The Implementation of Internal Quality Assurance System on Standard Content, Process and Assessment During Corona Virus Disease-19
}

\author{
K Kayatarno* \\ Department of Educational Administration, Post Graduate \\ Program \\ University of Mataram \\ Mataram, Indonesia \\ kayatarnoaji@gmail.com
}

Dadi Setiadi

Department of Educational Administration, Post Graduate Program

University of Mataram

Mataram, Indonesia

setiadi_dadi@unram.ac.id

\author{
R Rusdiawan \\ Department of Educational Administration, Post Graduate \\ Program \\ University of Mataram \\ Mataram, Indonesia \\ rusdiawan@ live .com \\ F Fahruddin \\ Department of Educational Administration, Post Graduate \\ Program \\ University of Mataram \\ Mataram, Indonesia \\ fahruddin.fkip@unram.ac.id
}

\begin{abstract}
The way to improve education quality is by implementing (Internal Quality Assurance System). This research aimed to examine the implementation of IQAS on content, process, and assessment standards during the covid-19 period at SDN 1 Dasan Tereng. This research used a qualitative approach with a case study method. Data were collected through observation, interviews and documents. Research result shows that in the Quality Mapping, teacher needs to increase competencies in preparing lesson plans, curriculum development, media use and authentic assessment. In the quality planning and implementation, workshop was held in preparing lesson plans, curriculum, media and authentic assessment. Meanwhile, in monitoring and evaluation, it was found that the curriculum workshop has not carried out yet and new quality standards have not implemented by school. Thus, school was not disciplined in implementing the Internal Quality Assurance System therefore the implementation of IQAS was not optimal.
\end{abstract}

Keywords - internal quality assurance system (iqas), school model, covid-19

\section{INTRODUCTION}

The education unit is obliged to provide services, facilitate and ensure the implementation of education quality for all students without discrimination in order to support the achievement goals on the national education. The implementation of education quality must be carried out in a directed, planned, and continuous manner by involving all school components [1] - [2] - [3], a holistic model [4] in order to produce the quality graduates who fulfill quality standards [5] - [2 ] which is the National Education Standards. This is the minimum standard set by the government in education, which the education unit must do. [1] - [6].

The way to fulfill the achievements of the National Education Standards is to implement a planned, repeated and continuous Internal Quality Assurance System [2] - [7] and supported by the environment [8] so that it develops into a habit or everyday quality culture [9] in education units. The government's effort to succeed the implementing of IQAS policy is by appointing a model school as a pilot project for implementing quality assurance independently. School model are schools that fostered by the Education Quality Assurance Institute (EQAI) to become reference for other schools in the vicinity in implementing quality assurance independently [10] - [11]. The school model that has been used as an IQAS pilot project by Education Quality Assurance Institute is SDN 1 Dasan Tereng, West Lombok (2017-2019). However, starting in 2020, this school is no longer a EQAI model school, because it is considered capable of implementing IQAS independently [11]. The question is: does SDN 1 Dasan Tereng disciplined in implementing the IQAS after quitting as a model school?

In 2020, the pandemic of Coronavirus Disease (Covid19) hit the world and spread to Indonesia. This caused the learning activities at schools especially SDN 1 Dasan Tereng replaced from offline to online learning policies [12] or work from home [13]. This policy led to changes in the learning system at schools, such as [14] limited face-to-face learning due to the online learning; [15] using text-based media (web, google classroom, WhatsApp), sound and text media (WhatsApp, audio), and video (Zoom, google meet, file share, and video); [16] distance learning by online and offline systems; [17] determining the learning design by noticing the available facilities and infrastructure. SDN 1 Dasan Tereng applies a combination of online and offline learning. It is due to out of 359 students, 313 people have facilities for online learning and the remaining 46 people do not have facilities. Therefore, the question is: Does SDN 1 Dasan Tereng disciplined in implementing the Internal Quality Assurance System during the pandemic of covid-19? 
From the description above, it is necessary to conduct a study on the implementation of IQAS on standard content, processes and assessments during covid-19 at SDN 1 Dasan Tereng after quitting as a school model. The purpose of this study was to determine the discipline of SDN 1 Dasan Tereng in implementing IQAS during the covid-19 after quitting as a school model.

\section{METHODS}

This research used a qualitative approach with the case study method. The research was conducted at SDN 1 Dasan Tereng. The research subjects consist of the principal, teachers, students, and the school committee. Data were collected through observation, interviews, and document. The instruments used in this study were interview, observation and document analysis guidelines. Data were analyzed using the Miles and Huberman model: data collection, data reduction, data display, and conclusion.

\section{RESULTS AND DISCUSSION}

The IQAS cycle consists of quality mapping, quality improvement planning, implementation of quality compliance, monitoring and evaluation, standards setting and new quality improvement strategies [18]. Schools should have procedures for quality assurance [2], resource acquisition and organizational allocation priorities; work management; strategic planning and implementation; staff recruitment, training and development [19]. The findings in this study are described through the 5 IQAS cycles, as follows:

Quality Mapping, is carried out by analyzing the school quality report that measured by grade [20] by the School Education Quality Assurance Team together with the school components, as the responsibility of all staff [8] which produces a quality map. The quality map contains school weaknesses, causes of weaknesses and suggested recommendations. The quality map of SDN 1 Dasan Tereng includes: Standard Contents, the school weaknesses where the learning equipment does not match the competency formulation of graduates, curriculum development does not comply with procedures and regulations. The reason is that there is lack of teachers' competence in preparing lesson plan and schools have not involved stakeholders in the curriculum development. Therefore, the problem lies in the teacher, curriculum, and contextual factors [3]. Standard Process, the school weakness is that teachers do not use media in the learning process. This is due to the reason that teachers do not know how to use the media exist. Hence, teachers are advised to improve their competence in utilizing learning media. It is seen that the problem comes from teachers [3]. Assessment Standard, the weakness of the school is that the teacher has not followed up on the assessment result, the assessment instrument is not in accordance with the aspects. The assessment is not carried out based on procedure. This reason was due teachers whose do not fully understand the assessment process. Moreover, the frequently change of the assessment regulations, lack of guidance, and teachers have not properly compiled the assessment instruments. In addition, teachers' competence regarding assessment needs to be increase due to the teacher and contextual factor problems [3].
Compliance Planning Quality is cycle that carried out by making an action plan by the School Education Quality Assurance Team based on the school quality map. Quality planning includes teachers' quality, accreditation and quality programs [21], teachers' factors, curriculum and contextual [3]. The forms of the action plan are: Standard Content, planning workshops for the preparation of learning tools and curriculum development workshops in order to help teachers more effectively in delivering curriculum [22]. Standard processes are part of planning a workshop on the use of learning media while Assessment Standards are part of planning an assessment workshop.

Implementation of Quality Compliance is a cycle carried out by carrying out all activities in the quality compliance plan. This activity is carried out with training and education to improve the quality of teachers [4] - [21]. Standard Content is a workshop for the preparation of learning tools which was held in July 2020 meanwhile the curriculum workshop which was originally held in August 2020 has not yet been implemented. Then, Process Standards is a media utilization workshop held at the end of semester 2 of 2020. Material: IT used (Whatsapp, zoom, google classroom, google form, and video) in learning. Assessment Standards is an assessment workshop held in June 2020 where the material use was the authentic 2013 curriculum assessment.

Monitoring and Evaluation is cycle that carried out by monitoring and evaluating the implementation of activities in the implementation cycle and carried out independently for continuous improvement [21] - [23] by the principal to understand the effect on academic performance [22], with the results: Standard content, workshops preparation of learning tools (well implemented) and curriculum development workshops (not implemented). In Standard process, workshop on the use of learning media was well implemented. On Assessment standard, the assessment workshop has already implemented.

Setting New Quality Standards and Formulating Quality Improvement Strategies are standardized programs that are supervised and are likely to be used extensively [24], but this cycle is not implemented because there is no monitoring and evaluation report yet.

The discussion on findings in this study was described through the following five cycles of the Internal Quality Assurance System: Quality Mapping, the SDN 1 Dasan Tereng School Education Quality Assurance Team has been able to carry out this cycle well. This can be seen from the preparation process involving all school components, the reference for its preparation is the achievement of the National Education Standards in the school quality report and the resulting quality map output [25] regarding the weaknesses of schools, the causes of weaknesses and recommendations in overcoming weaknesses. Finally, "The institution collects, analyzes, and uses relevant information for the management of study programs and activities" [2].

Compliance Planning Quality, the Education Quality Assurance Team at SDN 1 Dasan Tereng has been able to carry out this cycle by making a program action plan [2] although the plan is not optimal because it is not budgeted in the School Work Plan, there is no implementation schedule and the person who hold the responsibility in the activity. 
The output of quality compliance planning is a school development planning document and an action plan [25].

Implementation of Quality Compliance is [26] realizing all activities contained in the quality compliance planning document carried out by all stakeholders. The quality assurance team is tasked with quality assurance in the form of quality management implementation in a cycle [4]. However, this cycle cannot be implemented optimally due to the quality compliance planning that has been made. There is activity that has not been implemented which is the curriculum workshops. The School Education Quality Assurance Team has not worked optimally, they always depend on the principal's instructions so they do not have the initiative to carry out activities independently. Also, they have not made a report document on the implementation of activities [2] even though the staff involved should have the qualifications and competence.

Monitoring and evaluation is carried out to ensure that the implementation of quality compliance that goes according to plan. The output is a report on the implementation of the fulfillment on the National Education Standards and the implementation of the quality compliance plan, and recommendations for improvement [26] [27]. Institutions should have mechanisms for periodic review and monitoring programs [2]. The results of monitoring and evaluation activities at SDN 1 Dasan Tereng are that quality compliance planning is already good, implementation of quality compliance has not been carried out, but schools do not have activity reports, school principals do not have instruments and reports on monitoring and evaluation results, and the internal quality audit team has never carried out activity audits.

In the cycle of Establishing New Quality Standards and Formulating Quality Improvement Strategies, activities have not been carried out because there is no monitoring and evaluation report document, so there is no basis for the School Education Quality Assurance Team to make policies to set new standards and quality improvement strategies in the following year. As stated by [2] that "Institutions should regularly publish information about the programs they offer". The new standard helps schools to align activities effectively in order to improve the results quality [23]. Finally, [1] - [26] the indicators of success lie on the schools' ability in implementing the entire cycle of Internal Quality Assurance Standards and the formation of quality assurance organizations at schools.

\section{CONCLUSION}

Based on the findings and discussion, it is known that the Internal Quality Assurance Standard cycle that has not been implemented optimally lies in the implementation of quality compliance and monitoring evaluation. There is a cycle that is not implemented at all, which are the quality determination and new strategies. Therefore, SDN 1 Dasan Tereng was not disciplined in applying the Internal Quality Assurance Standards during the pandemic of covid-19 and after quitting as a school model. So, it can be concluded that the implementation of the Internal Quality Assurance Standards on content, process and assessment standards during the covid-19 period at SDN 1 Dasan Tereng after quitting a school model is said to be not optimal.

\section{REFERENCES}

[1] R. A. Sani, R. S. Arifin, M. Rif'an, and C. Triatna, Sistem Penjaminan Mutu Internal. Tangerang: TSmart, 2018.

[2] M. J. Manatos, C. S. Sarrico, and M. J. Rosa, "The European standards and guidelines for internal quality assurance: An integrative approach to quality management in higher education?," Emerald Insight TQM J., vol. 29, no. 2, pp. 1-20, 2017.

[3] G. T. U. Chiaha and S. O. Nane-Ejeh, "Quality Assurance Indicators for School Transformation: A Paradigm Shift," Int. Lett. Soc. Humanist. Sci., vol. 42, pp. 72-81, 2014.

[4] A. Suriansyah, "Implementation of The Total Quality Management Model to Support Qual-ity of Work Cultures at Primary School Teacher Education Programs in Lambung Mangkurat University Indonesia," Aust. J. Basic Appl. Sci., vol. 11, no. June, pp. 179-186, 2017.

[5] M. I. Bello, B. M. B. Ibrahim, and M. W. Bularafa, "Organisational capability in internalising quality culture in higher institution," J. Educ. Pract., vol. 6, no. 29, pp. 70-73, 2015.

[6] Nasyirwan, "Pencapaian 8 (Delapan) Standar Nasional Pendidikan Oleh Kepala Sekolah Untuk Meningkatkan Mutu Lulusan," Manajer Pendidik., vol. 9, no. 6, pp. 724-736, 2015

[7] S. Wilian, D. Setiadi, and N. Sridana, "Analysis of the Implementation of Internal Quality Assurance System in Private Islamic High Schools in Mataram-Lombok," vol. 438, no. Aes 2019, pp. 216-219, 2020.

[8] S. Cardoso, M. J. Rosa, P. Videira, and A. Amaral, "Internal quality assurance: A new culture or added bureaucracy?," Assess. Eval. High. Educ., vol. 44, no. 2, pp. 249-262, 2019.

[9] P. Praraksa, S. Sroinam, M. Inthusamith, and M. Pawarinyanon, “A Model of Factors Influencing Internal Quality Assurance Operational Effectiveness of the Small Sized Primary Schools in Northeast Thailand," Procedia - Soc. Behav. Sci., vol. 197, no. February, pp. 1586-1590, 2015.

[10] Darsimah, "Implementasi SPMI di SDN Wonotingal dapat Menumbuhkan Penguatan Karakter Pendidik dan Peserta Didik," Media Penelit. Pendidik. J. Penelit. dalam Bid. Pendidik. dan Pengajaran, vol. 14, no. 2, pp. 141-143, 2020.

[11] F. Rosdiana and U. R. Soedarmo, "Sistem Penjaminan Mutu dalam Mewujudkan Mutu Sekolah Pada Sekolah Model dan Sekolah Imbas," Indones. J. Educ. Manag. Adm. Rev., vol. 3, no. 1, pp. 1-6, 2019.

[12] I. F. Ahmad, “Asesmen Alternatif dalam Pembelajaran Jarak Jauh Pada Masa Darurat Penyebaran Coronavirus Disease (Covid-19) di Indonesia," J. Pedagog., vol. 07, no. 01, pp. 195-222, 2020.

[13] I. Setyorini, "Pandemi Covid-19 dan Online Learning: Apakah Berpengaruh Terhadap Proses Pembelajaran Pada Kurikulum 13?," J. Ind. Eng. Manag. Res., vol. 01, no. 1, pp. 95-102, 2020.

[14] M. Mastur, M. Afifulloh, and L. N. A. B. Dina, "Upaya Guru Dalam Melaksanakan Pembelajaran Daring Pada Masa Pandemi Covid-19," JPMI J. Pendidik. Madrasah Ibtidaiyah, vol. 2, no. 3, pp. 72-81, 2020 .

[15] T. Sudrajat, Omay Komarudin, Ni'mawati, and Q. Y. Zaqiah, "Inovasi Kurikulum dan Pembelajaran Pada Masa Pandemi Civid19,” J. Ilm. Wahana Pendidik, vol. 6, no. 3, pp. 317-322, 2020.

[16] A. M. Saifulloh and M. Darwis, "Manajemen Pembelajaran dalam Meningkatkan Efektivitas Proses Belajar Mengajar di Masa Pandemi Covid-19," Bidayatuna J. Pendidik. Guru Madrasah Ibtidaiyah, vol. 3, no. 2, pp. 285-311, 2020.

[17] P. Marbun, "Desain Pembelajaran Online Pada Era Dan Pasca Covid19,” CSRID J., vol. 12, no. 2, pp. 129-142, 2020

[18] R. Pamelanintyas, "Implementasi Program Sistem Penjaminan Mutu Internal (SPMI) di SMP Negeri 8 Yogyakarta," J. Kebijakan. Pendidik., vol. 8, no. 3, pp. 230-237, 2019 